\title{
Evolution of human longevity and the genetic complexity governing aging rate*
}

\author{
(primates/hominids/cranial capacity/body weight)
}

\author{
RICHARD G. CUTLER
}

Institute for Molecular Biology, University of Texas at Dallas, P.O. Box 688, Richardson, Texas 75080

Communicated by Richard B. Setlow, June 23, 1975

\begin{abstract}
Genetic complexity of processes governing the aging rate of man was estimated by determining the maximum rate lifespan has evolved along the hominid ancestral-descendant sequence. Maximum lifespan potential was found to have increased approximately 2 -fold over the past 3 million years, reaching a maximum rate of increase of 14 years per 100,000 years about 100,000 years ago. It is estimated that about $0.6 \%$ of the total functional genes have received substitutions leading to one or more adaptive aminoacid changes during this 100,000-year time-period. This suggests that aging is not the result of an expression of a large number of independently acting processes. Instead, primary aging processes appear to exist where only a few genetic changes are necessary to decrease uniformly the aging rate of many different physiological functions.
\end{abstract}

Maximum lifespan (MLS) potential is defined as the maximum observed lifespan of a species (1-3). This value is usually obtained with animals living under favorable conditions but does not vary greatly even over a wide range of living conditions. There is about a 50 -fold range of MLS potential for the mammalian species (1-4). However, the various types of age-dependent physiological dysfunctions and diseases are quite similar and are expressed in similar temporal patterns. This is not surprising, considering the similarities at the physiological, biochemical, and molecular levels for the mammalian species, and particularly for the primates, where a 10- to 12-fold difference in MLS potential is found (5-7). Thus, mammalian species appear to age qualitatively in the same manner, by the same types of biological processes, but at different rates that can vary over a 50-fold range $(3,8-10)$.

These types of observations had suggested that the genetic processes governing aging rate may not be too complex (8, $11,12)$. However, there are other arguments that suggest that the aging process is highly diverse and complex, involving many different genes acting independently of one another (13-18). If this were true, then a uniform increase in lifespan, maintaining the qualitative aspects of the aging process, would require a change in all of these genes.

In this paper, the genetic complexity of the processes governing aging rate in man is estimated by determining the highest rate at which MLS potential has evolved along the hominid ancestral-descendant sequence leading to modern man. This rate is compared to the range of evolutionary rates of other characteristics of mammals and to estimates of the maximum rate new genes could have evolved during this time period.

Abbreviations: MLS, maximum lifespan; yr, year.

* The material and conclusions of this paper were presented at the 27th Annual Scientific Meetings of the Gerontological Society in a symposium on "Evolution of Mammalian Longevity and Aging."

\begin{abstract}
RESULTS
Prediction of maximum lifespan potential and developmental rate

MLS potential can be predicted for most mammalian species with an accuracy of about $25 \%$ by use of the multiple allometric regression of lifespan on brain weight and body weight developed by Sacher $(1,19)$. This is illustrated in Table 1, where a comparison is made between observed and predicted MLS potentials for representative primate species of Old World monkeys, apes, and man. There is also an excellent correlation between the relative time period required to reach various stages of development and the MLS potential of these primates (20). A ratio of about five is found between MLS potential and the time period required to reach sexual maturity for the higher-ordered primate species.
\end{abstract}

\section{Estimation of maximum lifespan potential for the hominids}

The prediction of MLS potential for the primate species is equally good for the different "grades" of primate species (i.e., the living fossil-like species in Prosimii as compared to man) $(1,3,19)$. In addition, the hominid species are expected to have similar biological characteristics, and therefore similar aging processes, as observed in the primates, particularly between chimpanzee and modern man (7). Therefore, it is reasonable to expect that the prediction of MLS potential by the Sacher equation should also apply to the fossil hominid species.

The estimates of cranial capacities and body weights of species generally believed to be part of the ancestral-descendant sequence of hominid evolution are shown in Table 2 with their corresponding estimates of date of appearance. Approximately a 2-fold increase in MLS potential is predicted to have occurred over the last 3 million years of hominid evolution.

Estimates of the age at death for a few of these hominid species were available and are shown in Table 2 . These estimates are all substantially smaller than the predicted MLS potentials. The values, however, are not likely to represent MLS potential and would, therefore, be expected to be smaller. The method used to estimate the age at death is based on the assumption that the bone and tooth developmental rates in the hominids are similar to those in modern man $(38,42)$. This procedure may result in an important underestimation of the actual age at death for these hominids $(3,19)$. In Table 1 , it was shown that a constant ratio exists between sexual maturation age and MLS potential for the higher-ordered primates. This relation was used in Table 2 to predict the sexual maturation age for the hominids. The 
Table 1. Comparison between observed and predicted maximum lifespan potentials and developmental rates for some Old World monkeys, apes, and man

\begin{tabular}{|c|c|c|c|c|c|c|c|c|}
\hline \multirow[b]{2}{*}{ Genus and species } & \multirow[b]{2}{*}{ Common name } & \multirow[b]{2}{*}{ (Sex) } & \multirow[b]{2}{*}{$\begin{array}{c}\text { Body wt.a } \\
\text { (g) }\end{array}$} & \multirow{2}{*}{$\begin{array}{l}\text { Cranial } \\
\text { capacity } \\
\left(\mathrm{cm}^{3}\right)\end{array}$} & \multicolumn{2}{|c|}{ Lifespan (yr) } & \multicolumn{2}{|c|}{$\begin{array}{c}\text { Sexual maturation age } \\
(\mathrm{yr})\end{array}$} \\
\hline & & & & & $\begin{array}{c}\text { Ob- } \\
\text { servedb }\end{array}$ & $\begin{array}{c}\text { Pre- } \\
\text { dictedc }\end{array}$ & Observedd & Predictede \\
\hline Presbytis entellus & Langur & (ర) & 21,000 & 120 & 22 & 24 & $3-4$ & $4-5$ \\
\hline Macaca mulatta & Rhesus macaque & (ర) & 6,000 & 90 & 29 & 27 & $4-5$ & $5-6$ \\
\hline Papio cynocephalus & Western baboon & (ठ) & 22,000 & 200 & 32 & 35 & $5-6$ & $6-7$ \\
\hline Hylobates lar & Gibbon & (0) & 5,500 & 100 & 32 & 30 & $7-8$ & $6-7$ \\
\hline Pongo pygmaeus & Orangutan & (ठ) & 69,000 & 420 & 50 & 41 & $9-10$ & $8-9$ \\
\hline Gorilla gorilla & Gorilla & (ర) & 140,000 & 555 & 40 & 42 & $8-9$ & $8-9$ \\
\hline Pan troglodytes & Chimpanzee & (0) & 38,500 & 410 & 45 & 46 & $8-9$ & $8-9$ \\
\hline Homo sapiens modern & Man & $\begin{array}{l}\text { (0) } \\
(\%)\end{array}$ & $\begin{array}{l}65,000 \\
58,000\end{array}$ & $\begin{array}{l}1,450 \\
1,330\end{array}$ & 95 & $\begin{array}{l}92 \\
89\end{array}$ & $17-18^{f}$ & $17-18$ \\
\hline
\end{tabular}

These values are considered typical of the species and are from Schultz (20), Tobias (21), Jerison (22), and Stephan et al. (23). Most are rounded off to avoid appearance of high accuracy.

b Jones $(24,25)$, Biology Data Book (26), and Napier and Napier (27).

c Maximum lifespan values (MLS) were calculated from the Sacher equation (1): MLS $=(10.83)(\text { Brain wt., g) })^{0.636}(\text { Body wt., g) })^{-0.225}$. Differences in cranial capacity $\left(\mathrm{cm}^{3}\right)$ and brain wt. (g) are considered negligible for these calculations (23).

d Schultz (20) and Napier and Napier (27).

e Predicted from the equation: Sexual maturation age $=(0.2)($ MLS). This relation was experimentally determined for the higher-ordered primate species.

I Eighteen years is best estimate of sexual maturation about 200 years ago. It has since decreased from this value to $13.5 \mathrm{yr}(28)$.

results suggest that the general developmental rate was not constant, but steadily decreased with time along the hominid ancestral-descendant sequence.

The predicted MLS potential along the ancestral-descendant sequence of the hominids is shown in Fig. 1. It is found to increase steadily, reaching a maximum about 100,000 years ago, and then to remain essentially constant up to the present time. The MLS potentials and times of appearance of the hominid species were found to correspond closely to a linear relation (between 4 million and 100,000 years ago)

Table 2. Estimate of maximum lifespan potential and developmental rate for the hominids from fossil body weight and cranial capacity measurements

\begin{tabular}{|c|c|c|c|c|c|c|c|c|c|}
\hline \multirow[b]{2}{*}{ No. } & \multirow[b]{2}{*}{ Genus and species } & \multicolumn{2}{|c|}{ Body weight (kg) } & \multicolumn{2}{|c|}{$\begin{array}{c}\text { Cranial } \\
\text { capacity }\left(\mathrm{cm}^{3}\right)\end{array}$} & \multirow{2}{*}{$\begin{array}{c}\text { Time of } \\
\text { appearance } \\
\left(y r \times 10^{-6}\right)\end{array}$} & \multicolumn{2}{|c|}{$\begin{array}{l}\text { Maximum } \\
\text { lifespan (yr) }\end{array}$} & \multirow{2}{*}{$\begin{array}{c}\text { Predicted } \\
\text { sexual } \\
\text { maturation } \\
\text { age }(y r)^{f}\end{array}$} \\
\hline & & $\begin{array}{l}\text { Mea- } \\
\text { sureda }\end{array}$ & $\begin{array}{c}\text { Pre- } \\
\text { dicted }^{b}\end{array}$ & $\begin{array}{l}\text { Mea- } \\
\text { sureda }\end{array}$ & $\begin{array}{c}\text { Pre- } \\
\text { dictedc }\end{array}$ & & $\begin{array}{c}\text { Ob- } \\
\text { servedd }\end{array}$ & $\begin{array}{c}\text { Pre- } \\
\text { dictede }\end{array}$ & \\
\hline 1 & Ramapithecus punjabicus & 32 & - & 300 & 280 & 14 & - & 42 & $8-9$ \\
\hline 2 & Australopithecus africanus & 32 & 32 & 450 & 460 & 3 & $35-40$ & 51 & $10-11$ \\
\hline 3 & Australopithecus robustus & 40.5 & - & 500 & 490 & 2.5 & 35 & 52 & $10-11$ \\
\hline 4 & Australopithecus boisei & 47.5 & - & 530 & 530 & 2 & 一 & 52 & $10-11$ \\
\hline 5 & Homo habilis & 43 & 45.3 & 660 & 580 & 1.5 & - & 61 & $12-13$ \\
\hline 6 & Homo erectus javanicus & 53 & 52.3 & 860 & 740 & 0.7 & $40-60$ & 69 & $13-14$ \\
\hline 7 & Homo erectus pekinensis & 53 & 56.3 & 1040 & 1030 & 0.25 & $40-60$ & 78 & $15-16$ \\
\hline 8 & Homo europaeus pre-Würm & - & 57.6 & 1310 & 1380 & 0.1 & $40-60$ & 89 & $17-18$ \\
\hline 9 & Homo neanderthalensis europaeus & - & 58.1 & 1460 & 1500 & 0.045 & $40-60$ & 93 & $18-19$ \\
\hline 10 & Homo sapiens europaeus Würm & - & 58.4 & 1460 & 1480 & 0.015 & - & 94 & $18-19$ \\
\hline 11 & Homo sapiens recens & - & 58.4 & 1460 & 1480 & 0.01 & 90 & 94 & $18-19$ \\
\hline 12 & Homo sapiens modern & 63.5 & 58.5 & 1410 & 1360 & present & 95 & 91 & $18-19$ \\
\hline
\end{tabular}

Mean body weight estimates are taken from recent values based on fossil data (29-32), brain to body weight allometric relationships (33, $34)$, and a comparative basis $(29,33)$. Mean cranial capacity measurements for the hominid species were taken from the fossil data analyzed by Tobias (21), Parenti (35), and Pilbeam and Gould (33). Estimates are rounded off to avoid appearance of high accuracy. Some of the estimates are quite accurate and others only educated guesses. However, most values and times of appearance are considered to be accurate within $20 \%$.

b A near linear relationship was found between body weights of $A$. africanus, $H$. habilis, and $H$. erectus and time of appearance (3). Using this relationship, body weights were predicted when values were not available. Close agreement of the predicted body weights with the independently measured weights indicates that these predictions, where the measured values are not available, are reasonable.

c Predicted values of hominid cranial capacities were from two equations derived from a large number of fossil data presented by Lestrel and Read (36). These are: Brain wt. $(\mathrm{g})=55,745$ (time) - $^{-32}$ for time $=4 \times 10^{6}$ to $1.6 \times 10^{5}$ yr. (This equation represents my derivation from their data, and brain wt. $(\mathrm{g})=1321$ (time $)^{0.012}$ for time $=1.6 \times 10^{5}$ to $10 \mathrm{yr}$.) Close agreement of the independently measured cranial; capacities with the predicted capacities indicates that these values are reasonable.

a Based on fossil evidence (37-40) and survival time in primitive societies (41).

e From Sacher equation given in footnote in Table 1.

' From mean ratio of maximum lifespan to sexual maturation time of 5.0 (see Table 1 footnote). 


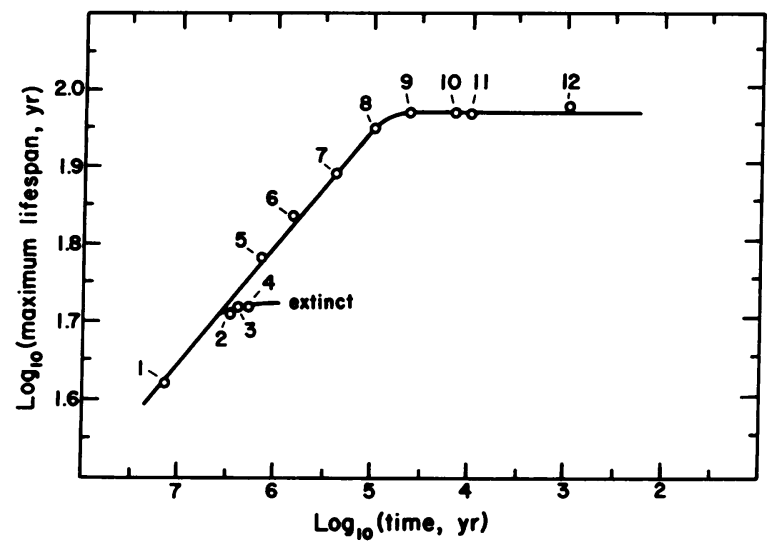

FIG. 1. Relationship between MLS potential and time of appearance of the hominid species. Numbers indicate genus and species of hominids listed in Table 2.

when plotted on $\log$ versus $\log$ coordinates. This relation was used to obtain an estimate of the rate of increase in MLS potential.

The similar MLS potentials for the gracile species A. africanus and the more robust species $A$. robustus and $A$. boisei suggest that a divergence occurred in the hominid lineage about 3-4 million years ago. It appears as if the robust species later became extinct. The absence of an increase in MLS potential along this lineage may have played an important role in the evolutionary failure of such new races.

\section{Rate of increase of maximum lifespan potential}

Estimates of the rate of increase in MLS potential are shown in Table 3 . The rate steadily increased, reaching a maximum

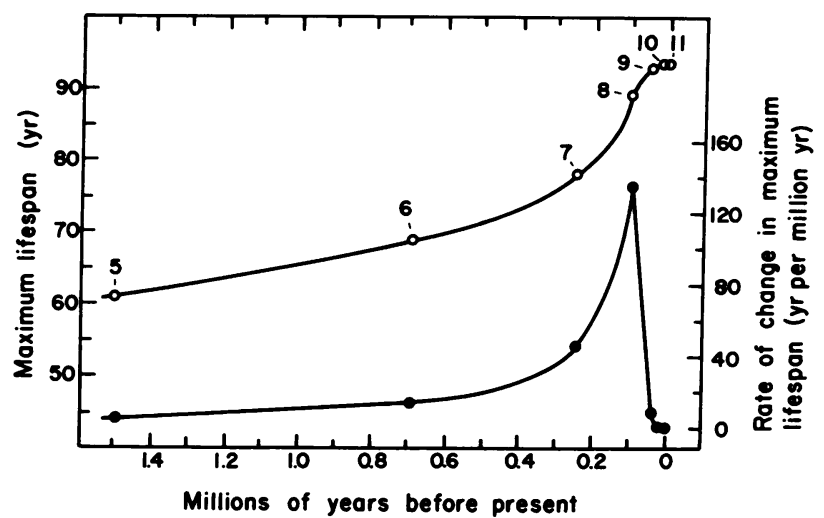

FIG. 2. Rate of increase in MLS notential along the ancestraldescendant sequence of the hominids !eading to modern man. Numbers indicate genus and species of hominids listed in Table 2. $(0)$, maximum lifespan, yr; (๑), rate of change in MLS potential, yr per million yr.

value of 140 years per million years approximately 100,000 years ago with the appearance of Homo europaeus preWürm and then rapidly decreased to zero. These results are shown in Fig. 2.

The nucleotide substitutions occurring during evolution are expected to have a wide range of effects. Although these changes have frequently been classified as being either deleterious, neutral, or advantageous, there is likely to be a continuous gradient of effects between these extremes (45-47). The mean rate of change in nucleotide pairs per genome along the ancestral-descendant sequence of the hominids since the divergence of the chimpanzee to the present time has been estimated to be $0.08 \%$ per million years according to fossil dating and $0.22 \%$ per million years according to al-

Table 3. Estimates of the evolutionary rate of increase in maximum lifespan potential along the ancestral-descendant sequence of the hominids leading to modern man

\begin{tabular}{|c|c|c|c|c|}
\hline No. & Genus and species & $\begin{array}{l}\text { Rate of increase } \\
\text { of MLS potential } \\
\left(\mathrm{yr} \text { per } 10^{6} \mathrm{yr}\right)^{\mathrm{a}}\end{array}$ & $\begin{array}{l}\text { Change in MLS } \\
\text { potential per percent } \\
\text { change in nucleotide } \\
\text { pairs }{ }^{b}\end{array}$ & $\begin{array}{c}\text { Rate of increase } \\
\text { in MLS potential } \\
\text { in millidarwin } \\
\text { unitsc }\end{array}$ \\
\hline 1 & Ramapithecus punjabicus & 0.5 & 2 & 4 \\
\hline 2 & Australopithecus africanus & 3 & 14 & 22 \\
\hline 3 & Australopithecus robustus & 2 & 9 & 14 \\
\hline 4 & Austrälopithecus boisei & 0 & 0 & 0 \\
\hline 5 & Homo habilis & 6 & 27 & 36 \\
\hline 6 & Homa erectus javanicus & 14 & 64 & 75 \\
\hline 7 & Homo erectus pekinensis & 47 & 210 & 220 \\
\hline 8 & Homo europaeus pre-Würm & 140 & 640 & 580 \\
\hline 9 & Homo neanderthalensis europaeus & 10 & 45 & 40 \\
\hline 10 & Homo sapiens europaeus Würm & 0 & 0 & 0 \\
\hline 11 & Homo sapiens recens & 0 & 0 & 0 \\
\hline 12 & Homo sapiens modern & 0 & 0 & 0 \\
\hline
\end{tabular}

Equation describing linear relationship shown in Fig. 1 between MLS potential and time of presence of a given hominid species is calculated as:

$$
\mathrm{MLS}=(518.8) t^{-0.153} \text { for } t=10^{7} \text { to } 0.1 \times 10^{6} \mathrm{yr}
$$

where the rate of increase of MLS (yr) per $10^{6} \mathrm{yr}$ is calculated from the equation:

$$
\frac{d \mathrm{MLS}}{d t}=(79.37) t^{-1.153}
$$

b Based on a mean value of $0.22 \%$ change in nucleotide sequences per genome per million years according to fossil dates along the ancestraldescendant sequence of the hominids leading to modern man, beginning with the divergence of the chimpanzee (43).

c Evolutionary rate in darwin units is calculated as (44):

where $e$ is the base of natural logarithms and is defined as one darwin unit.

$$
d=\frac{d \mathrm{MLS}}{d t} \cdot \frac{10^{6}}{\mathrm{MLS}} \cdot \frac{1}{e}
$$


bumin dating (43). These values represent the resultant fixation rate of all nucleotide pair changes occurring during hominid evolution (except those that are deleterious). The extent MLS potential changed with respect to these nucleotide substitutions is shown in Table 3 and indicates that a maximum increase of 6.4 years occurred per $0.01 \%$ change in nucleotide pairs.

Estimates of the evolutionary rate of increase in MLS potential in terms of darwins (44) are in Table 3. The darwin represents a rate of evolutionary change normalized with respect to the parameter being measured and is useful in comparing the evolutionary rate of other characteristics of animals during the course of their evolution. A maximum value of about $\mathbf{5 8 0}$ millidarwins for MLS potential is calculated with the appearance of Homo europaeus pre-Würm, approximately 100,000 years ago. Typical rates of evolution of many different characteristics for mammals are in the range of 30 millidarwins (48).

\section{DISCUSSION}

An average increase in MLS potential of approximately 2fold was found to have occurred over the past 3 million years along the hominid-ancestral descendant sequence. During this period, MLS potential increased and reached a maximum rate of 14 years per 100,000 years with the appearance of Homo europaeus pre-Würm, 100,000 years ago. An average increase of about 10 years in MLS potential or a $12.5 \%$ decrease in aging rate occurred between 200,000 and 100,000 years ago.

This 100,000-year time-period is used below to estimate the genetic complexity involved in governing the aging rate of the hominids. At the beginning and end of this interval, it is assumed that the qualitative spectra of aging processes are similar among the two populations of hominid species. To achieve this, it is assumed that most of the genes involved in governing aging rate are modified during this time period. However, because of the similarity of the aging processes among all the primate species, it is likely that the genes modified during this 100,000 -year period were the same at all stages of non-primate and hominid evolution $(3,10)$.

An upper limit to the number of genes governing the aging processes of the hominids can be determined from an estimate of the maximum number of genes which could have had one or more advantageous substitutions fixed during the 100,000-year time-period. This has been done using three different methods.

Haldane (49) has estimated that the maximum rate of adaptive gene substitution in mammalian evolution could not be more than one substitution per genome per 300 generations. Although this estimation has been accepted by $\mathbf{K i}$ mura and Ohta (50), it has been questioned and may possibly be an order of magnitude too low $(51,52)$. It is generally agreed that the maximum number of genes per genome for mammals could not exceed $4 \times 10^{4}(45,53,54)$. With this gene number and Haldane's estimate, the fixation rate is calculated to be $10^{-7} \mathrm{AA} /$ gene per generation (AA in aminoacid substitutions). This value is equivalent to $10^{-3} \mathrm{AA} / \mathrm{gene}$ per $10^{4}$ generations $\left(10^{4}\right.$ generations in a $10^{5}$-year period, assuming a generation time of 10 years). Assuming an even distribution of adaptive base substitutions along the genome, this rate predicts that on the average about 40 genes or $0.1 \%$ of the total functional genes received base substitutions leading to one or more adaptive amino-acid changes. This estimation method was also employed by Sacher (19).

The average rate that nucleotides have been fixed since the divergence of chimpanzee and man has been estimated, using a DNA hybridization technique, to be $0.08 \%$ according to fossil dates (43). Assuming an average gene size of 1000 nucleotide pairs and that substitution is evenly distributed along the genome, this value is equivalent to $6 \times 10^{-2}$ AA/gene per $10^{4}$ generations. A similar calculation for the average amino-acid substitution rate for a number of different proteins in mammals (including primates) gives a value of about $4.8 \times 10^{-2} \mathrm{AA} /$ gene per $10^{4}$ generations $(45,47)$. The amino-acid fixation rate may, however, be substantially lower during recent hominid evolution if it has continued to decrease, as some data have indicated $(43,55,56)$. For example, studies based on human and chimpanzee globins give 2 to $4 \times 10^{-3} \mathrm{AA} /$ gene per $10^{4}$ generations between Australopithecus and modern man (56). It therefore appears reasonable to assume that the rate of fixation of nucleotides over the entire genome during recent hominid evolution did not exceed the equivalent of $6 \times 10^{-2} \mathrm{AA} /$ gene per $10^{4}$ generations. This base fixation rate includes a broad and continuous spectrum of substitutions ranging from highly advantageous through completely neutral (including nonfunctional DNA) to a few even being slightly disadvantageous (46). Ohta and Kimura (57) have suggested $10 \%$ as an upper limit for adaptive substitutions. Using this estimate gives an adaptive fixation rate of about $6 \times 10^{-3} \mathrm{AA} /$ gene per $10^{4}$ generations. Assuming $4 \times 10^{4}$ genes per genome, it is predicted that about 250 genes or $0.6 \%$ of the total functional genes have received base substitutions leading to one or more adaptive amino-acid changes in 10,000 generations of hominid evolution.

It is also possible theoretically to calculate the rate of evolution of adaptive gene substitutions $(50,58) . N_{e}$ is taken to be $10^{4}$ [about 0.95 of the true population (58)], $\mu$ to be $10^{-9}$ AA/gene per generation [equivalent to about one advantageous mutation per $100,000(45,59)]$, and $s$ to be $10^{-2}$ (a moderately advantageous selective coefficient). These parameters give an adaptive fixation rate of $4 \times 10^{-3} \mathrm{AA} /$ gene per $10^{4}$ generations. Assuming an even distribution and $4 \times$ $10^{4}$ genes per genome as before, this rate predicts that about 160 genes or $0.4 \%$ of the total functional genes received base substitutions leading to one or more amino-acid changes.

These calculations suggest that two of the most complex features of man, longevity and intelligence, evolved extremely rapidly with surprisingly few point mutational changes occurring in the genome $(3,11,19)$. Other data have been reported suggesting relatively simple changes at the genetic level to account for complex phenotypic changes $(53,54,60)$. A particularly interesting suggestion is that changes in the genetic regulatory system by gene rearrangement may be a major process in the evolutionary development of the primates $(7,61-63)$.

According to these arguments and the data presented in this paper, the aging process in mammals might also be controlled at the gene regulatory level and not by changes in the amino-acid sequence of structural proteins. Thus, genetic regulatory changes of structural genes already present may be able to decrease uniformly the rate of expression of most mammalian aging processes.

Some support for this model has been reported $(3,9,10$, 12). The most significant in this respect is the correlation found between the extent of UV excision repair and MLS potential in a wide range of mammalian species (64). Recent evidence has indicated that this difference might be simply a result of different synthesis rates of similar repair enzyme(s) (65). 
If the information stability of DNA proves to be a major factor governing aging rate $(9,66)$, then an interesting prediction of these results is that mutation rate, acting as a primary aging process, may have actually decreased during the evolution of the primates. Other data have also indicated a decrease in mutation rate, and several explanations have been suggested $(43,47,55,56,67)$. One common explanation is that this effect might be the direct result of an increased generation time $(43,67)$. The answer may in fact be the reverse: that an increased generation time was the result and not the cause of the decrease in mutation rate $(3,11)$.

After this paper was completed, I learned that George Sacher has estimated the MLS potential during hominid evolution by the allometric regression method $(11,19)$. He also found a high rate of increase of longevity and inferred that this may have been accomplished by allelic substitution at a comparatively small number of loci. I am happy to acknowledge the encouragement received from George Sacher and the stimulating discussions with Dr. R. W. Hart and John Wulf. This research was supported by the following granting agencies: Biomedical Sciences Support Grant RR-07133 from the General Research Support Branch, Division of Research Resources, National Institutes of Health; The University of Texas at Dallas Research Fund; the Yarborough and Associates Research Fund; and the Glenn Foundation for Medical Research.

1. Sacher, G. A. (1959) in Ciba Foundation Colloquia on Aging (Churchill, London), Vol. 5, pp. 115-133.

2. Comfort, A. (1964) Ageing. The Biology of Senescence (Holt, Rinehart \& Winston, New York).

3. Cutler, R. G. (1975) J. Hum. Evol., in press.

4. Cutler, R. G. (1975) J. Hum. Evol., accepted for publication.

5. Napier, J. R. \& Napier, P. H. (1971) Old World Monkeys (Academic Press, New York).

6. Chiarelli, A. B. (1973) Evolution of the Primates (Academic Press, New York).

7. King, M. C. \& Wilson, A. C. (1975) Science 188, 107-116.

8. Cutler, R. G. (1972) in Adv. Gerontol. Res., ed. Strehler, B. L. (Academic Press, New York), Vol. 4, pp. 219-321.

9. Cutler, R. G. (1974) Mech. Ageing Dev. 2, 381-408.

10. Cutler, R. G. (1975) in Interdisciplinary Topics in Gerontolo$g y$, ed. Cutler, R. G. (Karger, Basel), Vol. 9, in press.

11. Sacher, G. A. (1970) in Report on the Continuing Conference on the Future. II. The Age of Synthesis, ed. May, M. (Center for Theoretical Biology, State University of New York, Buffalo, N.Y.), pp. 25-33.

12. Cutler, R. G. (1972) The Gerontologist 12, 40.

13. Medawar, P. (1957) The Uniqueness of the Individual (Basic Books, New York)

14. Williams, G. C. (1957) Evolution 11, 398-411.

15. Hamilton, W. D. (1966) J. Theor. Biol. 12, 12-45.

16. Wallace, D. C. (1967) J. Chronic Dis. 20, 475-486.

17. Maynard Smith, J. (1966) in Topics in the Biology of Aging, ed. Krohn, P. L. (Interscience, New York), pp. 1-35.

18. Weiss, P. (1966) in Perspectives in Experimental Gerontology, ed. Shock, N. (C. C Thomas, Springfield, Ill.), pp. 311322.

19. Sacher, G. A. (1975) in Proceedings of the International Congress Anthropological and Ethnological Sciences, IXth, Chicago, Sept., 1973 (published as Antecedents of Man and After. Vol. 1. Primates: Functional Morphology and Evolution), ed. Tuttle, R. (Mouton, The Hague), pp. 417-441.

20. Schultz, A. H. (1968) in Perspective on Human Evolution, eds. Washburn, S. L. \& Jay, P. C. (Holt, Rinehart \& Winston, New York), pp. 122-195.

21. Tobias, P. V. (1971) The Brain in Hominid Evolution (Columbia Univ. Press, New York)

22. Jerison, H. J. (1973) Evolution of the Brain and Intelligence (Academic Press, New York).

23. Stephan, H., Bauchot, R. \& Andy, O. J. (1970) in The Primate Brain, eds. Noback, C. R. \& Montagna, W. (Appleton-Century-Crofts, New York), pp. 289-297.
24. Jones, M. L. (1962) Lab. Primate Newslett. 1 (3), 3-13.

25. Jones, M. L. (1968) Int. Zoo Yearb. 8, 183-192.

26. Biology Data Book (1972) (Fed. Amer. Soc. Exp. Biol., Bethesda, Md.) 2nd ed., Vol. 1, pp. 229-230.

27. Napier, J. R. \& Napier, P. H. (1967) A Handbook of Living Primates (Academic Press, New York).

28. Roberts, D. F. (1971) in Anthropological Congress Dedicated to A. Hrdlička, ed. Novatny, V. V. (Academia, Prague), pp. 115-122.

29. Lovejoy, C. O. \& Heiple, K. G. (1970) Am. J. Phys. Anthrop. 32, 33-40.

30. Robinson, J. T. (1972) Early Hominid Posture and Locomotion (Univ. of Chicago Press, Chicago).

31. Wolpoff, M. H. (1973) Am. J. Phys. Anthrop. 39, 375-394.

32. McHenry, H. M. (1974) Am. J. Phys. Anthrop. 40, 329-340.

33. Pilbeam, D. \& Gould, S. J. (1974) Science 186, 892-901.

34. Holloway, R. L. (1974) Sci. Am. 231, (July) 106-115.

35. Parenti, R. (1973) J. Hum. Evol. 2, 499-508.

36. Lestrel, P. E. \& Read, D. W. (1973) J. Hum. Evol. 2, 405-411.

37. Vallois, H. V. (1960) in The Application of Quantitative Methods in Archaeology, eds. Heizer, R. \& Cook, S. (Quadrangle Books, Chicago), pp. 186-222.

38. Mann, A. E. (1968) The Paleodermography of Australopithecus (Univ. Microfilms, Ann Arbor, Mich.)

39. Janssens, P. A. (1970) Palaeopathology (John Baker, Ltd. London).

40. McKinley, K. R. (1971) Am. J. Phys. Anthrop. 34, 417-426.

41. Barwick, D. E. (1971) in Aboriginal Man and Environment in Australia, eds. Mulvaney, D. J. \& Goulson, J. (Aust. Nat. Univ. Press, Canberra), pp. 288-315.

42. Acsádi, G. \& Nemerskéri, J. (1970) History of Human Lifespan and Mortality (Akadémiai Kiadó, Budapest).

43. Kohne, D. E., Chiscon, J. A. \& Hoyer, B. H. (1972) J. Hum. Evol. 1, 627-644.

44. Haldane, J. B. (1949) Evolution 3, 51-56

45. King, J. L. \& Jukes, T. H. (1969) Science 164, 788-798.

46. Ohta, M. (1974) Nature 252, 298-300.

47. Langley, C. H. \& Fitch, W. M. (1974) J. Mol. Evol. 3, 161177.

48. Van Valen, L. (1974) Nature 252, 298-300.

49. Haldane, J. B. S. (1957) J. Genet. 57, 511-524.

50. Kimura, M. \& Ohta, T. (1971) J. Mol. Evol. 1, 1-17.

51. Maynard Smith, J. (1968) Nature 219, 1114-1116.

52. Sved, J. A. (1968) Am. Natur. 102, 283-293.

53. Ohno, S. (1972) J. Hum. Evol. 1, 651-662.

54. Ohno, S. (1974) Nature 244, 259-262.

55. Goodman, M., Koen, A. L., Barnabas, J. \& Moore, G. W. (1971) in Comparative Genetics in Monkeys, Apes and Man, ed. Chiarelli, A. B. (Academic, New York), pp. 153-212.

56. Goodman, M., Moore, G. W., Barnabas, J. \& Matsuda, G. (1974) J. Mol. Evol. 3, 1-48.

57. Ohta, T. \& Kimura, M. (1971) J. Mol. Evol. 1, 18-25.

58. Crow, J. F. \& Kimura, M. (1970) An Introduction to Population Genetics Theory (Harper \& Row, Publ., New York).

59. Corbin, K. W. \& Uzzell, T. (1970) Am. Natur. 104, 37-52.

60. Davidson, E. H. \& Britten, R. J. (1973) Quart. Rev. Biol. 48, 565-613.

61. Wilson, A. C., Maxson, L. R. \& Sarich, V. M. (1974) Proc. Nat. Acad. Sci. USA 71, 2843-2847.

62. Wilson, A. C., Sarich, V. M. \& Maxson, L. R. (1974) Proc. Nat. Acad. Sci. USA 71, 3028-3030.

63. Prager, E. M. \& Wilson, A. C. (1975) Proc. Nat. Acad. Sci., USA 72, 200-204.

64. Hart, R. W. \& Setlow, R. B. (1974) Proc. Nat. Acad. Sci. USA 71, 2169-2173.

65. Hart, R. W. \& Trosko, J. E. (1975) in Interdisciplinary Topics in Gerontology, ed. Cutler, R. G. (Karger, Basel), Vol. 9, in press.

66. Cutler, R. G. (1975) in Protein and Other Adducts to DNA Their Significance to Aging, Carcinogenesis and Radiation Biology, ed. Smith, K. C. (Plenum Press; New York), in press.

67. Ohta, T. (1972) J. Mol. Evol. 1, 150-157. 